\title{
A (IN)EFETIVIDADE DO INSTITUTO DO TOMBAMENTO COMO FORMA DE PRESERVAÇÃO DO PATRIMÔNIO HISTÓRICO E CULTURAL BRASILEIRO
}

\author{
THE (IN)EFFECTIVENESS OF HERITAGE LISTING POLICY AS A WAY TO \\ PRESERVE BRAZILIAN HISTORICAL AND CULTURAL HERITAGE
}

\author{
Otávio Martins Finger ${ }^{1}$ e André Augusto Cella ${ }^{2}$
}

\section{RESUMO}

A presente pesquisa tem como objetivo analisar a efetividade do instituto brasileiro do tombamento, forma de intervenção do Estado na propriedade utilizada para fins de proteção ao patrimônio histórico e cultural nacional. O estudo aborda, para tanto, os conceitos atinentes ao tombamento, a sua história no ordenamento, bem como as obrigações e efeitos decorrentes de sua instituição, sobretudo a impossibilidade de modificação dos bens tombados. São analisados, com o fim de avaliar a eficácia do instituto, casos relevantes de tombamento no Brasil, em especial o do edifício Wilton Paes de Almeida (SP) e o do prédio Eunice Andrew (RS), em razão de sua notoriedade recente. Por fim, investiga-se a necessidade de atualização legislação em matéria de preservação do patrimônio histórico e cultural. O método utilizado no presente estudo é o indutivo, uma vez que, a partir dos casos mencionados, bem como por meio de livros, legislação, jurisprudência e sítios eletrônicos, chega-se a uma conceituação do tombamento como modalidade de intervenção estatal na propriedade, concluindo-se, ao final, se o instituto é instrumento habilitado qualitativamente para a preservação da memória histórica e artística nacional. Nessa linha, levantam-se os seguintes questionamentos no presente trabalho: a limitação da propriedade pelo Estado, com o intuito de proteger o bem objeto do tombamento, é justificável? O tombamento é meio efetivo de preservação de um imóvel de valor histórico e cultural relevante?

Palavras-chaves: Inefetividade. Intervenção do Estado na propriedade. Patrimônio histórico. Tombamento.

\section{ABSTRACT}

This paper aims to analyze the effectiveness of heritage listing in Brazil, which is a form of State intervention in property used to protect cultural and historical national heritage. The research addresses, therefore, concepts linked to heritage listing, as well as obligations and effects which derive from its institution, specially the impossibility of making changes to listed heritages. It will be analyzed, with the purpose of evaluating the effectiveness of this policy, relevant cases of listed heritage sites in Brazil, mainly Wilton Paes de Andrade Building, in São Paulo (SP), and Eunice Andrew building, in Santa Maria (RS), because of their recent notoriety. After that, listed heritage legislation update needs will be investigated. The inductive method will be used in this paper, once a conception of heritage listing as a form of State intervention on property will be reached through research in the mentioned cases, books, legislation, judicial precedents and internet sites, contributing to the conclusion whether this policy is (or it is not) the adequate one to preserve national memory in arts and history. Following this line, questions will be raised in this paper: is the limitation of property rights by the State, done with the good intention of protecting heritage listed sites, justifiable? Is heritage listing an effective way to preserve historically and culturally important venues?

Keywords: Heritage listing. Historical heritage. Ineffectiveness. State intervention in property.

\footnotetext{
${ }^{1}$ Bacharel em Direito - Universidade Franciscana. E-mail: otaviofinger@gmail.com

${ }^{2}$ Professor de Direito Administrativo - Universidade Franciscana. E-mail: andrecella@gmail.com
} 


\section{INTRODUÇÃO}

O presente estudo tem por objetivo analisar, por intermédio da legislação, doutrina e jurisprudência pertinentes, o instituto do tombamento no Brasil, sobretudo no tocante à sua efetividade na preservação de bens historicamente relevantes.

Com o intuito de esclarecer a temática, é de suma importância referir que o tombamento se caracteriza como uma das formas de intervenção do Estado na propriedade. Doutrinariamente, há divergência quanto à sua natureza jurídica, sendo que alguns autores o classificam como uma modalidade de servidão administrativa, enquanto outros entendem ser forma autônoma de intervenção.

Em vista disso, o tema da presente pesquisa é de grande relevância e atualidade, tendo em vista os recentes acontecimentos envolvendo imóveis tombados no país. O desabamento do edifício Wilton Paes de Almeida, em São Paulo, SP, e a demolição das ruínas do prédio do Colégio Centenário, em Santa Maria, RS, ambos no ano de 2018, são alguns dos exemplos que serão tratados neste trabalho e que fazem emergir a discussão acerca da aplicabilidade do instituto do tombamento.

É cediço que a preservação do patrimônio cultural e artístico nacional é direito difuso, encontrando respaldo na Constituição Federal de 1988. Entretanto, resta saber, à vista mais pragmática, se o tombamento é meio qualificado para garantir tal direito previsto na Carta Magna, uma vez que, em determinados casos, tal proteção é ineficaz, como nos exemplos supramencionados.

Nesse sentido, levando em conta o estado de precariedade que se encontra o instituto do tombamento no Brasil, é que se justifica a presente pesquisa. Torna-se necessária a reanálise, à luz do Direito Civil e do Direito Administrativo, da restrição imposta pelo Estado ao particular, sendo esta, por muitas vezes, a razão da degradação e do abandono de imóveis tombados.

Assim, este trabalho limitar-se-á a investigar a validez do tombamento como forma de preservação do patrimônio histórico e cultural e como modalidade de intervenção do Estado na propriedade.

Por fim, é perfeitamente conciliável o objeto deste trabalho com a linha de pesquisa adotada pelo Curso de Direito da Universidade Franciscana, qual seja, Teoria Jurídica Cidadania e Globalização, porquanto trata da preservação do patrimônio cultural arquitetônico brasileiro, direito difuso indispensável ao exercício da cidadania e à vida na urbs.

\section{A PROTEÇÃO DO PATRIMÔNIO HISTÓRICO E CULTURAL NO BRASIL}

O ideal de proteção do patrimônio histórico surgiu em meados do século XIX, no processo de formação do Estado nacional. No Brasil, tal matéria foi tratada expressamente, pela primeira vez, na Constituição de 1934, após ganhar relevância no período da República Velha e do Governo Provisório de Getúlio Vargas, instituído em 1930. 
A Carta Fundamental de 1934 dedicou-se, no seu art. 10, III, a prever a competência concorrente da União e dos Estados para "proteger as belezas naturais e os monumentos de valor histórico ou artístico, podendo impedir a saída de obras de arte" (BRASIL, 1934).

Dentre as políticas públicas do período, a fim de dar efetividade ao mandamento constitucional, houve a criação do Serviço do Patrimônio Histórico e Artístico Nacional (SPHAN), órgão ao qual competia, conforme a Lei no 378 de 1937, "promover em todo o País, e de modo permanente, o tombamento, a conservação, o enriquecimento e o conhecimento do patrimônio histórico e artístico" (BRASIL, 1937).

O órgão do SPHAN, posteriormente transformado em IBPC e atualmente conhecido como IPHAN (Instituto do Patrimônio Histórico e Artístico Nacional), autarquia federal, se mantém como a instituição mais antiga da América Latina com o objetivo de promover a preservação de bens culturais (PIRES, 1994, p. 36).

Após a instauração da Ditadura de Getúlio Vargas, em 1937, e a consequente dissolução do Parlamento brasileiro, foi outorgada a Carta de 1937, a qual subsumiu a mesma questão em seu art. 134:

Art 134. Os monumentos históricos, artísticos, e naturais, assim como as paisagens ou os locais particularmente dotados pela natureza, gozam da proteção e dos cuidados especiais da Nação, dos Estados e dos Municípios. Os atentados contra eles cometidos serão equiparados aos cometidos contra o patrimônio nacional. (BRASIL, 1937)

A nova disposição constitucional, de viés programático, obedeceu à índole nacionalista do Estado Novo. A expedição de decretos-leis ficou a cargo do Presidente, em razão da destituição do Congresso com a Carta de 1937. Vargas ocupou-se, então, de tratar do tema no Decreto-Lei no 25/37, o qual instituiu o tombamento, ponto central deste estudo, e que será conceituado mais à frente (PIRES, 1994, p. 36-37).

As Cartas Magnas que se seguiram, incluindo a Constituição da República de 1988, continuaram "reservando a qualificação do patrimônio à legislação ordinária e sujeitando à proteção do poder público os bens que constituem o patrimônio histórico, artístico, cultural e paisagístico" (PIRES, 1994, p. 37).

A atual Carta Maior, ainda nesta linha, ampliou a definição de patrimônio cultural em seu art. 216, conceito que, até então, estava restrito ao subsumido no Decreto-Lei no 25/37. Assim dispõe o referido dispositivo constitucional:

Art. 216. Constituem patrimônio cultural brasileiro os bens de natureza material e imaterial, tomados individualmente ou em conjunto, portadores de referência à identidade, à ação, à memória dos diferentes grupos formadores da sociedade brasileira, nos quais se incluem:

I - as formas de expressão;

II - os modos de criar, fazer e viver;

III - as criações científicas, artísticas e tecnológicas;

IV - as obras, objetos, documentos, edificações e demais espaços destinados às manifestações artístico-culturais;

$\S 1^{\circ} \mathrm{O}$ Poder Público, com a colaboração da comunidade, promoverá e protegerá o patrimônio cultural brasileiro, por meio de inventários, registros, vigilância, tombamento e desapropriação, e de outras formas de acautelamento e preservação. (BRASIL, 1988) 
Vislumbra-se do artigo que o constituinte se preocupou em englobar tanto o tombamento quanto outras formas de preservação, possibilitando a expansão da proteção a que se submetem os bens culturais.

Acerca da competência prevista no $\S 1^{\circ}$ do art. 216, depreende-se que o constituinte de 1988 utilizou-se “da expressão Poder Público, isto é, refere-se a qualquer dos membros da Federação brasileira, ao responsabilizar o Estado, juntamente com a sociedade, pela promoção e proteção dos bens culturais por meio de inventários, registros, vigilância, tombamento, desapropriação etc.” (COSTA, 2011, p. 46).

É visível a preocupação com a proteção do patrimônio histórico e cultural, uma vez que, desde o ano de 1934, é dado caráter constitucional à temática. Diante de tal previsão, foram instituídos métodos para preservação de bens culturalmente relevantes, sendo o tombamento o mais importante deles.

\section{BREVE ANÁLISE DO DECRETO-LEI No 25/1937 NO CENÁRIO DITATORIAL DO ESTADO NOVO}

Conforme referido anteriormente, o Decreto-Lei no 25/37 surgiu em um contexto histórico no qual se buscava um ideal de pátria, sendo que a ideologia de Getúlio Vargas procurava simbolizar, em monumentos, o Estado-Nação Brasil. O tombamento foi a forma encontrada para proteger esses bens historicamente valiosos.

Sob o governo de Vargas, explorou-se no Brasil "a criação de símbolos para a formação identitária da nação" (REIS; FONSECA, 2016, p. 62, apud PIRES, 2010, p. 76), próprios do nacionalismo getulista, dentre eles o patrimônio material de relevância histórica. Émilien Vilas Boas Reis e Renato Penido Fonseca citam PIRES (2016, p. 62), ao discorrerem seu entendimento a respeito do contexto histórico no qual surgiu o tombamento:

\footnotetext{
A busca por uma identidade nacional resultou na salvaguarda de bens determinados, vinculados a 'fatos memoráveis da história do Brasil'. Elegeram-se, segundo Pires 'critérios de seleção para fins de conformação do patrimônio símbolo o caráter excepcional do bem e o seu enquadramento na tipologia urbana e arquitetônica do século XVIII', caracterizada pelo barroco colonial e suas representações.
}

Com o Decreto-Lei n ${ }^{\circ}$ 25/37, concretizou-se a ideia de proteção ao patrimônio histórico material, trazida anteriormente pela Constituição de 1934 e ampliada na Carta de Vargas de 1937.

Sobre a expedição do aludido decreto-lei em período democraticamente contestável, leciona oportunamente Rodrigo Vieira Costa (2011, p.55):

Embora tenha surgido, quanto à forma, por via legislativa típica de estados de exceção, isto é, um Decreto-Lei, como foi o promulgado por Getúlio Vargas, em 10 de novembro de 1937, com o fechamento do Congresso Nacional, a proposta inicial do tombamento era para ser concebida como lei ordinária. Antes do Estado-Novo de Vargas, o projeto havia sido apreciado e aprovado em primeira deliberação pela Câmara dos Deputados. Logo após, 
houve a derrocada do Estado democrático e consequente transformação do projeto de lei do tombamento no Decreto-Lei no 25, de 30 de novembro de 1937.

Nessa mesma esteira discorre Maria Coeli Simões Pires (1994, p. 37), acrescentando que, apesar do período histórico em que se encontrava o país, a legislação expedida por Vargas foi resultado da pressão de intelectuais:

Esse decreto-lei, conquanto tenha sido fruto e instrumento da Ditadura de Vargas, do autoritarismo estatal, inegavelmente, resultou de aprofundados estudos, da sensibilidade de alguns políticos da época e das pressões dos intelectuais na busca da revalorização da cultura nacional e constitui-se em documento-chave da matéria. É ele verdadeiro somatório das experiências e contribuições das elites, assimiladas ao longo de uma luta em favor da institucionalização da proteção ao patrimônio histórico, artístico, cultural e paisagístico, além de ter introduzido a prática da limitação dos direitos patrimoniais em função de interesses sociais sem a consequência necessária de indenizar.

Destarte, denota-se que o Decreto-Lei n ${ }^{\circ} 25 / 37$, não obstante tenha entrado em vigor em conturbada época, inaugurou no Brasil a questão da limitação do direito de propriedade ante o interesse público de proteção do patrimônio histórico e cultural.

O tombamento previsto no decreto-lei de Vargas permaneceu vigente em todas as ordens constitucionais brasileiras, tendo sido "recepcionado pela Constituição vigente com o status de lei ordinária". À vista disso, "o instituto do tombamento em nenhum momento desde a sua instituição foi declarado inconstitucional" (COSTA, 2011, p. 56).

\section{TOMBAMENTO: CONCEITOS E APONTAMENTOS DOUTRINÁRIOS}

Embora tenha sido acolhido pela Carta Maior de 1988, por meio do fenômeno da recepção constitucional, o tombamento vem sendo objeto de questionamento, seja no campo da intervenção do Estado na propriedade, seja no tocante ao cumprimento de sua finalidade precípua, qual seja, a proteção do patrimônio histórico e artístico nacional. Nesse sentido, para que haja o entendimento pleno dessa problemática, faz-se necessária a conceituação do instituto, bem como de alguns termos que o envolvem.

Maria Sylvia Zanella Di Pietro (2014, p. 146), em breves palavras, define: “O tombamento é forma de intervenção do Estado na propriedade privada, que tem por objetivo a proteção do patrimônio histórico e artístico nacional [...]”. Semelhante definição oferece José dos Santos Carvalho Filho (2015, p. 836): “Tombamento é a forma de intervenção na propriedade pela qual o Poder Público procura proteger o patrimônio cultural brasileiro".

Outrossim, de maneira mais pormenorizada, Hely Lopes Meirelles (2015, p. 684-685) conceitua o tombamento como "a declaração pelo Poder Público do valor histórico, paisagístico, turístico, cultural ou científico de coisas ou locais que, por essa razão, devam ser preservados, de acordo com a inscrição 
em livro próprio". O autor ainda acrescenta: “A proteção de todos esses bens é realizada por meio do tombamento, ou seja, da inscrição da coisa em livros especiais - Livros do Tombo - na repartição competente, para que sua utilização e conservação se façam de acordo com o prescrito na respectiva lei.”

Portanto, através da inscrição do bem no respectivo Livro do Tombo, é que se caracteriza o tombamento, surgindo, a partir daí, as obrigações a quem quer que seja o proprietário.

Sobre a origem da expressão "tombo", explica Eduardo Tomasevicius Filho (2004, p. 245): "Costuma-se dizer que a preservação de bens culturais surgiu com a inscrição de determinados bens no livro localizado na Torre do Tombo, em Portugal, e daí o nome de tombamento".

O instituto do tombamento está intimamente ligado ao princípio da função social da propriedade, uma vez que o proprietário do bem tombado se submete a diversas obrigações, como a de preservar o bem e a de se abster de construir. Acerca disso também discorre Tomasevicius Filho (2004, p. 233):

O fundamento do tombamento é a função social da propriedade, que modificou o conteúdo
do direito de propriedade, ao impor ao titular desse direito a harmonização de seu exercício
com o interesse público, o qual está na preservação desse patrimônio, implicando a produção
de efeitos sobre o conteúdo desse direito, por meio da obediência aos deveres instituídos ao
titular do direito.

Nesta linha, o tombamento, que é por natureza um instituto de Direito Administrativo, se relaciona com o Direito Civil, coadunando-se intrinsecamente com a função social da propriedade ao estabelecer obrigações ao proprietário. É dizer que, uma vez tombado o bem, através de procedimento administrativo, emergem as obrigações ao proprietário, limitando o pleno gozo do direito de propriedade.

A respeito dessa restrição ao direito de propriedade do indivíduo, importante salientar que o proprietário poderá usar e gozar do bem, mas não o alterar, de modo que seus poderes ficam parcialmente elididos a partir do tombamento. Ainda, o titular fica obrigado, às suas expensas, a resguardar o valor da coisa e a mantê-la em boa conservação, salvo no caso de ausência de recursos, quando poderá solicitar ao Poder Público o custeio (BANDEIRA DE MELLO, 2015, p. 935).

Sobre o efeito de impossibilidade de modificação dos bens tombados, leciona José dos Santos Carvalho Filho (2015, p. 846):

Compete ao proprietário o dever de conservar o bem para mantê-lo dentro de suas características culturais. É dele, pois, a responsabilidade de reparação do imóvel, salvo quando provada a ausência de condições financeiras. Mas, se não dispuser de recursos para proceder a obras de conservação e reparação, deve necessariamente comunicar o fato ao órgão que decretou o tombamento, o qual mandará executá-las a suas expensas.

Nesta senda, os efeitos provenientes do tombamento se reproduzem quanto à alienação, deslocamento, transformação, conservação e fiscalização do bem. Ademais, aos imóveis vizinhos é limitado o direito de construir, vez que não podem impedir ou reduzir a visibilidade da coisa tombada, consoante artigo 18 do Decreto-Lei $n^{\circ}$ 25/37. 
Por conseguinte, resultam, do tombamento, “obrigações positivas (de fazer), negativas (não fazer) e de suportar (deixar fazer); para os proprietários de imóveis vizinhos, obrigações negativas (não fazer)" (DI PIETRO, 2014, p. 151).

Como já aludido, a ideia de se tombar um bem particular advém do interesse público que há em se preservar um bem historicamente importante. Neste âmbito, como em tantos outros no Direito Administrativo, prevalece o princípio da supremacia do interesse público sobre o privado.

Celso Antônio Bandeira de Mello (2015, p. 62), define interesse público como sendo o interesse resultante do somatório de interesses que os indivíduos pessoalmente têm quando considerados como membros da Sociedade como um todo. Significa dizer que o interesse público não é somente o interesse de uma integralidade abstrata, mas também o interesse de vários membros do corpo social.

Dessa forma, o interesse público assim se realiza quando o Estado, representante da Sociedade, cumpre de maneira satisfatória seu papel, que no caso do tombamento é a preservação do patrimônio histórico e cultural. Em outras palavras, o interesse público consiste na melhor realização possível, pelo ente estatal, da vontade expressa na Constituição e dos valores fundamentais nela contidos (BARROSO, 2018, p. 97-98).

Além de estar relacionado com os princípios da função social da propriedade e da supremacia do interesse público sobre o privado, o tombamento obedece também ao princípio da proteção do entorno, previsto expressamente no artigo 18 do Decreto-Lei $n^{\circ} 25 / 37$ e implicitamente nos artigos $7^{\circ}$ e $8^{\circ}$ da Carta Internacional de Veneza de 1964.

A referida Carta (1964) assim dispõe:

Artigo $7^{\circ}$ - O monumento é inseparável da história de que é testemunho e do meio em que se
situa. Por isso, o deslocamento de todo o monumento ou de parte dele não pode ser tolerado,
exceto quando a salvaguarda do monumento o exigir ou quando o justificarem razões de
grande interesse nacional ou internacional
Artigo $8^{\circ}$ - Os elementos de escultura, pintura ou decoração que são parte integrante do
monumento não lhes podem ser retirados a não ser que essa medida seja a única capaz de
assegurar sua conservação.

O princípio da proteção do entorno refere-se, assim, à necessidade de se manter o bem tombado inserido no contexto cultural em que se situa, de modo a caracterizar os elementos históricos de uma época. Para isso, além da proteção concedida ao próprio bem tombado, o seu envolto deve igualmente ser protegido.

O artigo 18 do Decreto-Lei no 25/37 (1937) prevê que não se poderá fazer construção que impeça ou reduza a visibilidade do bem tombado, ou inserir anúncios e cartazes ao seu redor, sem prévia autorização do IPHAN, sob pena de destruição da construção ou retirada do objeto, além de multa.

Nesse sentido, Rodrigo Vieira Costa (2011, p. 81) discorre sobre o princípio: 
O artigo 18 do Decreto-Lei $n^{\circ}$ 25/37 abriga este preceito basilar aplicável ao tombamento no ordenamento jurídico brasileiro. Ele protege vizinhança e visibilidade do bem tombado. Sua importância reside no resguardo da área em volta do patrimônio material afetado pelo instituto em comento, já que este também produz efeitos no direito de terceiros. Afinal, no ato de inscrição em um dos Livros do Tombo, o espaço envolto também é delimitado, de modo que não prejudique a sua acessibilidade e fruibilidade pelos cidadãos, no gozo do exercício dos direitos culturais.

Diante disso, denota-se que os princípios essenciais que abrangem o tombamento são o da função social da propriedade, o da supremacia do interesse público sobre o privado e o da proteção do entorno.

No que concerne às modalidades de tombamento, tem-se que o instituto pode ser constituído: 1) de ofício, quando incide sobre bens públicos, devendo se proceder à notificação do ente federativo a quem o bem pertença; 2) voluntariamente, quando há requisição para se tombar o bem por parte do proprietário, ou quando o mesmo anui com a notificação expedida pelo Poder Público; 3) compulsoriamente, realizado contra a vontade do proprietário do bem (DI PIETRO, 2014, p. 148).

Ademais, o tombamento pode ser classificado como provisório ou definitivo, tendo em vista a eficácia do ato que o institui. Será provisório a partir do momento em que o proprietário é notificado sobre o procedimento administrativo e intimado a se manifestar. À exceção da necessidade de transcrição no Registro de Imóveis, o tombamento provisório tem os mesmos efeitos do tombamento definitivo, o qual se efetiva com a inscrição do bem no respectivo Livro do Tombo (DI PIETRO, 2014, p. 148).

Em vista disso, a deterioração do bem provisoriamente tombado se equipara à deterioração do bem tombado de modo definitivo, ou seja, o sujeito que de qualquer maneira destruir ou se desfazer do bem estará sujeito às sanções administrativas do Decreto-Lei no 25/1937, bem como à pena do crime previsto no artigo 62 da Lei $n^{\circ}$ 9.605/1998 (COSTA, 2011, p. 90-91).

A provisoriedade do tombamento não poderá se estender ad aeternum. Impugnada a notificação de tombamento pelo particular, o Conselho Consultivo do Patrimônio Cultural terá sessenta dias para proferir decisão em relação ao tombamento por meio de parecer técnico, conforme dispõe os $\operatorname{artigos} 9^{\circ}$ e 10 do Decreto-Lei $n^{\circ}$ 25/37. Decorrendo o referido prazo sem manifestação, ficará caracterizado o abuso de poder e violação ao direito de propriedade, não mais podendo se dar continuidade ao procedimento (COSTA, 2011, p. 90-91).

Nesse ponto, entende-se haver a necessidade da notificação dos terceiros proprietários de bens do entorno do tombo, para fins de acompanhamento do processo e eventual contestação à inclusão da área do imóvel, uma vez que o tombamento geraria efeitos a estes proprietários vizinhos (COSTA, 2011, p. 92).

Ressalta-se, por fim, que o tombamento poderá ser individual ou geral, tendo em vista sua incidência. Será individual quando afetar um só bem individualizado, e geral quando incidir sobre um conjunto de bens (PIRES, 1994, p. 154).

A doutrina diverge quanto a possibilidade de se tombar bens imateriais. Para Maria Sylvia Zanella Di Pietro (2014, p. 147), o tombamento não sofreria qualquer restrição nesse sentido, podendo “atingir bens de qualquer natureza: móveis ou imóveis, materiais ou imateriais, públicos ou privados". 
Por outro lado, Maria Coeli Simões Pires entende que o instrumento de proteção do tombamento não incluiria como objeto bens imateriais, uma vez que a natureza do instituto seria intrinsecamente incompatível com tais bens (1994, p. 85). Rodrigo Vieira Costa (apud CUNHA FILHO, 2000, p. 111-112) compactua dessa posição:

\begin{abstract}
Neste momento, cabe uma questão: poderão, efetivamente, bens de natureza imaterial ser tombados? O tombamento para coisas intangíveis não seria inócuo, uma vez que quando se adota tal procedimento o que se quer é uma perenização do aspecto do bem tombado pelo maior tempo possível? Que efeito prático existe no ato de tombar uma dança, uma língua ou uma feira de artesanato? É aconselhável e possível estabelecer controle às influências que sofrem tais bens?

Refletindo sobre estas questões, alguns dos que se dedicam ao tema continuam a achar que, mesmo após o advento da Constituição 1998, o tombamento se adequa somente aos bens materiais, sendo que a forma de proteção das manifestações deve ser feita por outros meios como, por exemplo, o registro e o cadastramento.
\end{abstract}

Como se vê, para fins de proteção dos bens imateriais, se dá como alternativa o registro, instituto característico que atende ao dinamismo das manifestações culturais, as quais estão sujeitas à modificação pelo decurso do tempo e pela convivência com outras culturas. O registro de bens de natureza imaterial é regulado pelo Decreto $\mathrm{n}^{\mathrm{o}} 3.551 / 2000$, o qual foi expedido após estudos do IPHAN nessa área (PATRIMÔNIO..., 2019).

Sobre a possibilidade de se indenizar o particular pelo tombamento do seu bem, a posição majoritária é de que, em regra, o instituto não gera direito à compensação pecuniária. Nessa linha, entende-se que a compatibilidade entre tombamento e indenização só poderia ser analisada conforme o caso concreto.

Para Di Pietro (2014, p. 147), sendo o tombamento uma restrição parcial da propriedade e não havendo, assim, restrição quanto ao uso, gozo e fruição do bem, não há que se falar em indenização. Segundo a autora, para haver direito à indenização, o particular deverá comprovar o efetivo prejuízo resultante do tombamento.

Ao relacionar o tombamento com o instituto da desapropriação e com a função social da propriedade, Maria Coeli Simões Pires (1994, p. 261) complementa:

O princípio da função social não pode converter-se em expressão que sirva de panaceia, abrigando toda sorte de interesses em detrimento do direito igualmente constitucional de propriedade e justificando até o confisco.

Ora, a limitação à propriedade é que é excepcional. Em certos casos, melhor eliminar de vez a propriedade do que sujeitá-la a peias de toda natureza.

A função social justifica a servidão do tombamento ou até a desapropriação; não pode fazer desaparecer, porém, o direito à indenização, no primeiro caso, se se reconhecer prejuízo real e, no segundo, de qualquer modo, porque se negou a própria essência da propriedade. Em ambas as situações, a indenização corresponde à distribuição equânime do ônus da preservação cultural, dentro do princípio a solidariedade social. 
Destarte, entende-se que, em certas circunstâncias, poderá o proprietário buscar judicialmente indenização correspondente ao prejuízo causado pelo tombamento, mormente quando este afetar os componentes do direito de propriedade constitucionalmente previsto. Tal possibilidade relaciona-se com a natureza jurídica do tombamento, que será pormenorizada mais adiante.

Por fim, importante assinalar a possibilidade de se proceder ao cancelamento do tombamento. À luz do preceituado no Decreto-Lei no $25 / 37$, mais especificamente no seu artigo $9^{\circ}$, parte final, a decisão acerca do tombamento não era passível de recurso. Todavia, o Decreto-Lei $n^{\circ} 3.866 / 41$ revogou tal dispositivo, facultando ao Presidente da República, atendidos motivos de interesse público, deliberar sobre o cancelamento do tombamento em grau de recurso, interposto por qualquer interessado (DI PIETRO, 2014, p. 150-151).

Neste caso, salienta Rodrigo Vieira Costa (2011, p. 93-94): “o interesse público tem que estar concatenado aos reclames sociais até porque o cidadão e os legitimados da Lei $\mathrm{n}^{\circ} 7.347$, de 24 de julho de 1985, podem impugnar a anulação do tombamento pela via judicial, por meio da Ação Popular e da Ação Civil Pública, respectivamente".

Além da hipótese acima prevista, o cancelamento do tombamento poderá ser efetuado em razão de violação do procedimento administrativo regulado em lei, ou por instauração de outro processo. Em tal situação, dá-se oportunidade de manifestação ao particular, à sociedade e ao Conselho do Patrimônio Cultural, preservando-se, assim, os princípios constitucionais da legalidade, ampla defesa e contraditório (COSTA, 2011, p. 94).

Cumpre assinalar, ainda, que a promoção do tombamento no Estado do Rio Grande do Sul fica sob responsabilidade do Instituto do Patrimônio Histórico e Artístico do Estado - IPHAE. A Lei Estadual $\mathrm{n}^{\mathrm{o}} 7.231 / 1978$, que trata da proteção do patrimônio cultural do Estado, determina em seu artigo $2^{\circ}$ a aplicabilidade da legislação federal, de modo que há obediência às disposições do Decreto-Lei no 25/1937 para fins de tombamento de bens (RIO GRANDE DO SUL, 1978).

Especificamente na cidade de Santa Maria, RS, o tombamento é previsto como forma de proteção ao patrimônio histórico e cultural no artigo 195 da Lei Orgânica do Município. O processo de tombamento de edificações é regido pela Lei Municipal no 3.999/1996, que dispõe também acerca das competências do Conselho Municipal do Patrimônio Histórico e Cultural de Santa Maria COMPHIC-SM (SANTA MARIA, 1990, 1996).

\section{NATUREZA JURÍDICA}

A natureza jurídica do tombamento levanta divergências relevantes na doutrina de Direito Administrativo, merecendo, por isso, especial atenção. Primeiramente, questiona-se se o ato administrativo de tombamento é vinculado ou discricionário. Em segundo lugar, se o tombamento constitui servidão administrativa, limitação administrativa ou modalidade autônoma de intervenção na propriedade privada. 
Acerca do primeiro questionamento, prevalece a ideia de que o ato de tombar é, de fato, um ato discricionário da Administração Pública. $\mathrm{O}$ ato discricionário é aquele que pode ser praticado "com liberdade de escolha de seu conteúdo, de seu destinatário, de sua conveniência, de sua oportunidade e do modo de sua realização" (MEIRELLES, 2015, p. 186).

Filia-se a essa posição Maria Sylvia Zanella Di Pietro (2014, p. 154), que assim discorre:

\begin{abstract}
Há quem entenda que, colocando, a Constituição, os bens do patrimônio histórico e artístico nacional sob a proteção do poder público, a autoridade competente para determinar o tombamento (inscrição no Livro do Tombo) não pode deixar de fazê-lo quando o parecer do órgão técnico reconhecer o valor cultural do bem para fins de proteção. Ocorre que o patrimônio cultural não é o único bem que compete ao Estado proteger. Entre dois valores em conflito, a Administração terá que zelar pela conservação daquele que de forma mais intensa afete os interesses da coletividade. Essa apreciação terá que ser feita no momento da decisão diante do caso concreto; evidentemente, se nenhuma razão de interesse público obstar o tombamento, este deve ser feito; por isso mesmo, a recusa em fazê-lo há de ser motivada, sob pena de transformar-se a discricionariedade em arbítrio que afronta a própria Constituição, na parte em que protege os bens de interesse público.
\end{abstract}

Coaduna-se a tal entendimento Maria Coeli Simões Pires (1994, p. 120-121), assinalando que, embora o conteúdo do ato, os passos de sua execução e as mudanças produzidas juridicamente estejam previstas em lei, a Administração pode escolher o bem a ser contemplado pelo ato, bem como o momento oportuno para se proceder ao tombamento. Assim, por mais que o instituto detenha pressupostos vinculados, o fundamento último do ato fica a cargo da vontade política da autoridade administrativa.

Em relação ao segundo aspecto sobre sua natureza jurídica, diverge a doutrina ao enquadrar o tombamento como limitação administrativa, servidão administrativa ou forma própria de intervenção do Estado.

A Professora Sonia Rabello de Castro (2009, p. 139-140) classifica o tombamento como sendo uma limitação administrativa, uma vez que o instituto restringe, tanto para o particular como para a vizinhança, a faculdade de uso e gozo da propriedade, em razão do interesse público de proteção do patrimônio cultural. O tombo traduz-se, em verdade, numa limitação de uso acoplada a uma obrigação de fazer, qual sendo, a conservação da coisa. Nesse caso, só incidiria indenização ao particular em situações excepcionais.

Por outro lado, Maria Coeli Simões Pires (1994, p. 132) considera que o tombamento é, na verdade, uma servidão administrativa. A limitação administrativa, para a autora, acarreta tão somente em normas de caráter negativo ao proprietário, de restrição à sua propriedade. Diferente da limitação, o tombamento também se caracteriza como uma intervenção positiva no bem. O Estado interfere, nessa situação, sobretudo para assegurar o direito à cultura e promover o interesse público, sendo uma ação positiva que decorre da ideia de um Estado-social. À vista disso, se estaria diante de uma servidão administrativa pelo tombamento, tendo em conta inclusive a obrigação de suportar imposta ao proprietário.

Contrário aos posicionamentos acima expostos, o entendimento dominante é de que o tombamento é forma autônoma de intervenção do Estado na propriedade, não estando atrelado à servidão 
administrativa e tampouco à limitação administrativa. Nessa linha disserta Maria Sylvia Zanella Di Pietro (2014, p. 155):

O tombamento tem em comum com a limitação administrativa o fato de ser imposto em benefício de interesse público; porém dela difere por individualizar o imóvel.

Comparado com a servidão, o tombamento a ela se assemelha pelo fato de individualizar o bem; porém dela difere porque falta a coisa dominante, essencial para caracterizar qualquer tipo de servidão, seja de direito público ou privado.

Preferimos, por isso considerar o tombamento categoria própria, que não se enquadra nem como simples limitação administrativa, nem como servidão.

Celso Antônio Bandeira de Mello (2015, p. 935) também passou a defender tal posição, diferenciando o tombamento e a servidão administrativa em três pontos distintos:

\begin{abstract}
a) a servidão é um direito real sobre coisa alheia ao passo que o tombamento também pode afetar um bem próprio e ser satisfeito mesmo quando o bem de terceiro é expropriado, sem que com isto se extingam o gravames inerentes ao tombamento, não vigorando o princípio de que nemini res sua servit;

b) a servidão não impõe ao titular do bem tombado o dever de agir, pois não se lhe exige um facere, mas tão só um pati, ao passo que o tombamento constitui o titular do bem tombado no dever de conservá-lo em bom estado, no que se incluem todas as realizações de reformas para tanto necessárias;

c) demais disto, as servidões só oneram bens imóveis e o tombamento tanto pode se referir a bens imóveis quanto a bens móveis, como quadros, estatuetas, joias e outros objetos de interesse cultural.
\end{abstract}

Dessa forma, tem-se que a natureza jurídica do tombamento é de forma autônoma de intervenção do Estado na propriedade, tendo em vista as características e requisitos peculiares do instituto.

Isto posto, tendo em mente os conceitos necessários à compreensão do tombamento e de seus efeitos, conduz-se ao segundo momento da presente exposição, onde serão analisados alguns precedentes, com o objetivo de determinar se, de fato, o instituto é meio eficaz para a proteção do patrimônio histórico e cultural do Brasil.

\title{
A NECESSIDADE DE ATUALIZAÇÃO DAS NORMAS ATINENTES À PROTEÇÃO DO PATRIMÔNIO HISTÓRICO E CULTURAL
}

Conforme explanado alhures, o tombamento impõe obrigações ao proprietário e aos seus vizinhos, com o fim de preservar o bem objeto do tombo e suas características. O objetivo principal a partir desses efeitos é garantir o direito cultural à preservação do patrimônio histórico, constitucionalmente previsto.

Todavia, as obrigações impostas muitas vezes não são cumpridas, e a fiscalização por parte do Poder Público é precária. Assim, o mandamento constitucional de se preservar a história nacional não é satisfeito pelo tombamento, tornando o instituto infeliz em sua função precípua. 
Nesse sentido, os efeitos e obrigações decorrentes do tombamento são objeto de críticas. Émilien Vilas Boas Reis e Renato Penido Fonseca (2016, p. 67) reprovam o instituto, aduzindo que:

Diante das obrigações decorrentes do instituto do tombamento, especialmente às concernentes ao efeito da imodificabilidade dos bens culturais, muitos proprietários veem o tombamento como uma usurpação do direito de propriedade, infligindo no imóvel um esvaziamento do seu valor econômico. No intuito de evitá-lo, parcela dos proprietários de edificações tombadas as abandonam, mutilam e, em casos mais graves, promovem a demolição de toda edificação numa tentativa de alcançar o seu "destombamento".

A imutabilidade dos bens culturais se mostra um entrave diante da inovação tecnológica e da necessidade de criação de novos espaços, resultando em abandono e deterioração de alguns bens. Para se atingir o ideal de preservação do patrimônio, o bem tombado requer um uso racional, além da simples contemplação de seus elementos históricos e culturais.

Outrossim, em virtude da imodificabilidade do imóvel tombado, o proprietário abandona o bem por não ver nele nenhuma utilidade, bem como por estar obrigado a preservá-lo, sendo que muitas vezes não possui os recursos necessários para tanto. Ressalta-se também a postura relapsa do Estado, que, descumprindo a obrigação que lhe é imposta pelo Decreto-Lei no 25/1937, não realiza a vistoria recorrente nos bens tombados, inclusive naqueles que já foram abandonados.

Nesse sentido, foi realizado um estudo na cidade de São Paulo, SP, pelo periódico O Estado de São Paulo, que constatou que " $40 \%$ (quarenta por cento) dos 1.813 imóveis tombados ou em processo de tombamento de toda a capital estão abandonados, destruídos ou totalmente desfigurados" (AGÊNCIA ESTADO, 2009).

Na cidade de Campinas, no mesmo estado, a taxa é ainda maior. Cerca de $60 \%$ (sessenta por cento) dos bens tombados no Município estão em estado de abandono e necessitam de restauração. Para Daisy Ribeiro, gestora do Conselho de Defesa do Patrimônio Cultural de Campinas, o descaso se deve à carência de recursos públicos e à falta de uma cultura compartilhada de preservação do patrimônio histórico (G1, 2013).

Além de problemas envolvendo bens tombados definitivamente, mister assinalar que a demora no procedimento administrativo de tombamento também é causa relevante para deterioração dos bens, fragilizando ações de conservação.

No Município de Fortaleza, no Ceará, 54 (cinquenta e quatro) bens imóveis se encontram na condição de tombamento provisório, sendo que nove estão há mais de 10 (dez) anos com o processo em andamento. A provisoriedade torna ainda mais precária a materialização da proteção (NASCIMENTO, 2019).

Não obstante a concessão de incentivos aos proprietários em determinados Municípios, os custos que estes têm em manter o imóvel tombado geralmente é alto. Despesas com a preservação do bem, pagamento do IPTU e eventualmente queda do valor de mercado do imóvel fazem com que os gastos sejam maiores do que os benefícios concedidos (EXAME, 2018). 
Os custos elevados decorrentes do tombamento e a morosidade do procedimento administrativo gera a indignação e o descontentamento dos proprietários, que muitas vezes contestam o tombamento judicialmente, levantando ilegalidades e requerendo o destombamento do imóvel.

Nessa linha, afigura-se pertinente citar a decisão exarada na Apelação Cível no 003488954.2011.8.26.0564, do Tribunal de Justiça do Estado de São Paulo, de Relatoria do Desembargador Roberto Martins de Souza. No acórdão, decidiu-se pela caducidade do ato administrativo de tombamento provisório, em razão do excesso de prazo para conclusão do processo. Entendeu-se que a condição de tombamento provisório por prazo excedente ao estabelecido em lei inviabiliza a fruição plena do direito de propriedade, configurando abuso de poder (BRASIL, 2014).

Vislumbra-se, por conseguinte, que a lentidão de procedimentos administrativos se deve em grande parte à organização burocrática do executivo brasileiro, que contribui para a inefetividade do instituto do tombamento e é causa determinante na deterioração do patrimônio histórico e cultural brasileiro.

\section{ANÁLISE CASUÍSTICA: OS EDIFÍCIOS WILTON PAES DE ALMEIDA (SP) E EUNICE ANDREW (RS)}

Como já demonstrado, o abandono de bens tombados tem se tornado recorrente. A imodificabilidade dos imóveis e a atuação do Poder Público inviabiliza o uso racional e a atualização arquitetural, de modo que a permanência nestes bens não se mostra rentável. Nesse sentido, dois casos específicos podem ser citados a fim de evidenciar a ineficácia do tombamento como meio garantidor do direito difuso à preservação do patrimônio histórico.

O primeiro é o caso do edifício Wilton Paes de Almeida, localizado na capital paulista. Inaugurado em 1968 e famoso pelas fachadas envidraçadas, o prédio de 24 andares foi projetado para ser a sede da Companhia Comercial Vidros do Brasil, tendo abrigado, posteriormente, a sede da Polícia Federal e uma agência do INSS. A edificação era conhecida na década de 1960 como "pele de vidro", em razão de seu aspecto modernista (MESQUITA; SOUZA; BARIFOUSE, 2018).

Ainda, segundo reportagem contida no sítio eletrônico do G1, o prédio "havia sido tombado em 1992 por ser considerado ‘bem de interesse histórico, arquitetônico e paisagístico', o que garantia 'a preservação de suas características externas"'.

Após a mudança de sede da Polícia Federal, a edificação foi abandonada. Passou a ser ocupada por movimentos sociais, abrigando moradores e vendedores de rua, sem pagamento de qualquer contraprestação ao proprietário. A situação precária, a partir de então, se alastrou, com o alagamento de banheiros, proliferação de insetos e mofo nas paredes do edifício (MESQUITA; SOUZA; BARIFOUSE, 2018).

Objeto de um leilão sem interessados no ano de 2015, o prédio foi cedido pela União à Universidade Federal de São Paulo, para ali instalar a Faculdade de Direito do Largo do Paissandu. Como o projeto não teve sucesso, a condição miserável da construção permaneceu (SCAFF, 2018). 
A história do edifício Wilton Paes de Almeida ganhou repercussão somente depois do dia $1^{\circ}$ de maio de 2018, quando um incêndio de grandes proporções tomou conta do local e o prédio acabou desabando (SCAFF, 2018).

O sítio eletrônico do Jornal da Universidade de São Paulo (2018) divulgou sobre o ocorrido:

\begin{abstract}
Uma morte foi confirmada em decorrência da tragédia que atingiu o prédio, tombado pelo patrimônio histórico e local de uma ocupação irregular. Ao falar sobre o caso para a Rádio USP, o professor Valdir Pignatta e Silva, do Departamento de Engenharia de Estruturas e Geotécnica da Escola Politécnica da Universidade de São Paulo, disse que tudo indica - a partir das notícias e vídeos divulgados - que o edifício apresentava um excesso de aspectos de risco, como fiação elétrica exposta, botijão a gás em local com probabilidade de incêndio e o que chama de quebra de compartimento vertical, que ocorre quando um pavimento não está "serrado" em relação ao superior, o que contribui bastante com a propagação do incêndio, uma situação bastante semelhante ao que ocorreu no passado, quando dos incêndios dos edifícios Joelma e Andraus.
\end{abstract}

Nota-se no caso alhures que, ainda que tenha sido tombado a fim de preservar suas características históricas relevantes, o aludido edifício mostrava-se em condições deploráveis, decorrentes da ação do tempo e da ocupação irregular por famílias carentes.

Assim, a condição de bem tombado do edifício Wilton Paes de Almeida não impediu a ocupação ilegítima do local, o abandono por parte do Poder Público e a degradação da construção no decorrer dos anos. Nessa perspectiva, evidencia-se que o tombamento foi infeliz em sua missão constitucional.

Outro importante caso a ser mencionado foi o do prédio Eunice Andrew, pertencente ao Instituto Metodista Centenário, localizado em Santa Maria, RS. Construída na década de 1920 para abrigar o Colégio Metodista, a edificação partiu da ideia de duas educadoras norte-americanas, Miss Eunice Andrew e Miss Louise Best, missionárias da Igreja Metodista dos Estados Unidos. Em 1998 vinculou-se ao colégio a Faculdade Metodista de Santa Maria - FAMES, formando o Instituto (MAGALHÃES, 2013).

Conforme sítio eletrônico do periódico Diário de Santa Maria (2018), o prédio, consumido por um incêndio no ano de 2007, foi deixado em ruínas, vindo a ser tombado provisoriamente pelo Município de Santa Maria em 2015, a pedido de uma associação de ex-alunos. O tombamento definitivo do prédio sobreveio em 2016.

Ainda segundo o jornal (DIÁRIO DE SANTA MARIA, 2018), em 2017 o edifício foi objeto de ação judicial proposta pelo Instituto Metodista Centenário, que solicitava a demolição do prédio em razão do risco de desabamento. A ação ordinária tinha como ré a Prefeitura de Santa Maria, figurando o Ministério Público na condição de custos legis. Após uma série de decisões judiciais contraditórias, o Instituto, amparado por uma tutela provisória concedida pelo Tribunal de Justiça, iniciou a demolição das ruínas em maio de 2018.

A tutela antecipada, conferida em sede de Agravo de Instrumento, veio a ser confirmada no acórdão da Apelação Cível no 70080937352, julgada pela Segunda Câmara Cível do Tribunal de 
Justiça do Estado do Rio Grande do Sul, em 24 de abril de 2019. Nas razões do recurso, o Instituto Metodista Centenário mencionou que o processo de tombamento do edifício se fundou na importância histórica e cultural do bem, não tendo sido levado em consideração, entretanto, o estado estrutural do prédio e o efetivo risco que este passou a representar para a comunidade local. Sustentou o desinteresse na discussão do tombamento, buscando tão somente a demolição do bem, que é protegido (BRASIL, 2019, p. 3).

A Desembargadora Relatora, Lúcia de Fátima Cerveira, após proceder a uma breve narrativa dos fatos, expôs as razões pelas quais a apelação merecia provimento. Sustentou que o prédio, tal qual como se encontrava, não atendia aos interesses de conservação histórica, já que não era mais passível de recuperação. Frisou as manifestações contraditórias externadas pelo Município de Santa Maria, que, apesar de ter procedido ao tombamento definitivo em 2016, deferiu licença para a demolição do edifício, tendo posteriormente revogado a autorização. Destacou, inclusive, que a referida revogação não se deu em razão da condição de bem tombado, mas sim em virtude da colidência de documentos cadastrais do imóvel (BRASIL, 2019 p. 13-15).

Outrossim, a Relatora ressaltou que, apesar nas disposições de imodificabilidade do tombamento, contidas no artigo 17 do Decreto-Lei ${ }^{\circ}$ 25/1937, restou suficientemente comprovado que o prédio, com algumas estruturas ainda em pé, apresentava risco de iminente desabamento. Salientou a prova apresentada pelo Instituto, no sentido de demonstrar que inexistia a possibilidade de estabilização ou reforma do imóvel, sendo que o Município e o Ministério Público em nenhum momento comprovaram a viabilidade da manutenção das ruínas. Por fim, esclareceu que a procedência do recurso não impediria eventual discussão acerca da responsabilidade pela deterioração do bem, uma vez que se tratava de imóvel tombado (BRASIL, 2019, p. 16-20). Em vista disso, votou pelo provimento da apelação, para o fim de julgar procedente a ação ajuizada pelo Instituto Metodista Centenário. Os demais desembargadores, por unanimidade, votaram de acordo com a Relatora.

No julgado apresentado denota-se, novamente, que o tombamento em nada colaborou para a preservação do patrimônio histórico. O edifício Eunice Andrew sofreu com intempéries ao longo do tempo e, quando passou a apresentar perigo aos cidadãos, a única saída encontrada foi a demolição completa e programada do prédio.

À vista desses exemplos, bem como considerando o efeito de imodificabilidade dos bens tombados, vislumbra-se que a proteção ao patrimônio histórico e cultural, função primordial do instituto do tombamento, "não tem se mostrado efetiva", uma vez que "a funcionalidade de determinados bens culturais não correspondem à realidade urbana local” (REIS; FONSECA, 2016, p. 69).

Destarte, diante do descaso com os bens culturais e da consequente inefetividade do tombamento para se atingir o propósito de proteção do patrimônio histórico, vislumbra-se a necessidade de atualização normativa, de modo a simplificar e uniformizar a legislação nacional. 

HISTÓRICO E CULTURAL

Como já demonstrado, o tombamento se mostra inadequado para alcançar o propósito constitucional de preservação do patrimônio histórico e cultural, ficando sujeito à procedimentos burocráticos e decisões conflitantes por parte do Poder Executivo municipal, estadual e federal. Isso se deve, inclusive, à antiguidade do Decreto-Lei n ${ }^{\circ}$ 25/1937, que permaneceu vigente no ordenamento jurídico brasileiro durante todas as ordens constitucionais desde a Carta de 1937.

A carência de atualização de normas como a Lei do Tombamento faz com que o objetivo de preservação da cultura e história nacional, declarado na Constituição Federal de 1988, não seja plenamente cumprido. Faz-se necessária a modernização da legislação, cogitando-se a possibilidade de sua unificação.

Nas palavras de Rodrigo Vieira Costa (2011, p. 147), "a nova realidade constitucional para a cultura, apesar de representar um progresso, trouxe algumas indagações de ordem problemática de: sobre o que, como, quando, quem e quais limites proteger e fomentar nesta seara". Segundo o autor, “a legislação cultural infraconstitucional, principalmente no plano federal, é caótica".

Mister frisar que o Decreto-Lei nº 25/1937, até então, não passou por uma revisão legislativa minuciosa. As divergências doutrinárias decorrentes da norma são inúmeras, e envolvem tanto a natureza e a finalidade do instituto quanto a necessidade de alteração do conteúdo e do processo que permeiam o tombamento (CORDIDO, 2014, p. 299).

Nessa linha, evidenciada a precariedade do tombamento e a confusão legislativa nos diferentes entes federativos, observa-se que reformas se mostram necessárias para garantir o direito constitucional de preservação do patrimônio histórico e cultural. Em outras palavras, almeja-se a adaptação da legislação cultural, de modo a aproximá-la das várias instituições da sociedade civil, tornando simples e célere o processo de proteção ao patrimônio histórico.

Sobre a ancianidade da Lei do Tombamento e a necessidade de modernização do corpo legal atinente à cultura, Rodrigo Vieira Costa (2011, p. 148) leciona:

\footnotetext{
O inventário parcial dessas normas, presentes no primeiro capítulo, em relação à cronologia, demonstra que uma parte delas é anterior à ordem constitucional vigente, elaboradas em momentos distintos da história brasileira e do mundo, sendo, portanto, necessário averiguar sua desatualização e recepção frente tanto à sociedade contemporânea, quanto à própria Constituição de 1988. Ainda dentro dessa perspectiva, há um espaçamento desses mecanismos, vezes normas de hierarquia distintas, o que pode gerar choques de ordem tanto formal quanto substancial, ocasionando o comprometimento da segurança nas relações jurídicas.
}

Como visto, anomalias como a confusão de ordem hierárquica na legislação podem comprometer o preceito maior de preservação da história nacional, dificultando as ações do Executivo que promo- 
vam essa temática. Assim, impõe-se a correção de tais problemas a partir de uma legislação una, que trate de maneira otimizada acerca dos direitos culturais e da proteção ao patrimônio histórico e cultural.

A "Lei Geral de Cultura" repararia eventuais contratempos decorrentes da burocracia e do federalismo brasileiro, reunindo disposições sobre produção, incentivo, e acesso à cultura, assim como direitos autorais e preservação do patrimônio histórico, modernizando, de certo modo, o Decreto-Lei no 25/1937 (COSTA, 2011, p. 149).

A unificação legislativa nesse âmbito haveria também de abrigar os distintos mecanismos utilizados no Brasil, não só o tombamento. Institutos como o registro e o inventário estariam previstos na mesma lei.

Além disso, a adoção de institutos novos e adequados, constituição de incentivos significativos para os proprietários dos bens protegidos, inclusive por intermédio da isenção de impostos, são alguns exemplos de reformas viáveis para o fim de se garantir o direito à preservação do patrimônio histórico e cultural (PIRES, 1994, p. 289).

Importante exemplo a ser citado é o da legislação portuguesa. A lei unificada lusitana, qual seja, a Lei $n^{\circ}$ 107/2001, apesar de abrigar um conceito restrito de patrimônio histórico e cultural, excluindo bens naturais, organiza-se em torno de princípios basilares a serem seguidos nesse tema (PORTUGAL, 2001).

Outrossim, a lei portuguesa prevê de maneira concisa a atuação estatal, os direitos e deveres dos cidadãos para com o patrimônio histórico, bem como o objeto e o âmbito da proteção jurídica do patrimônio. Dispõe sobre as formas de proteção e seu procedimento, sobre a organização administrativa do Estado nesse âmbito e os incentivos fiscais aos proprietários de bens protegidos. Por fim, ainda trata da tutela penal do patrimônio cultural (PORTUGAL, 2001).

Institutos como a inventariação obrigatória de bens culturais públicos e privados a nível nacional, previstos na legislação lusitana, configuram um importante método de levantamento sistemático e atualizado do patrimônio cultural. Considerando a proximidade cultural, linguística e jurídica que se com Portugal, a lei geral de cultura daquele país pode servir como base para a atualização legislativa brasileira (COSTA, 2011, p. 154).

Diante da insuficiência do instituto do tombamento e do Decreto-Lei no 25/1937 para fins de proteção do patrimônio histórico e cultural no Brasil, essencial buscarem-se modelos que obtiveram maior sucesso no cenário internacional, tendo em vista a relevância do direito difuso à cultura.

Na Constituição Federal de 1988, percebe-se "a preocupação do constituinte com a tutela do patrimônio cultural brasileiro" (DI PIETRO, 2014, p. 145). Todavia, como visto, a preocupação não se reflete na legislação infraconstitucional, uma vez que o ordenamento é confuso e, mormente a Lei do Tombamento, transmite o ideal de uma ordem constitucional diversa da atual.

Desse modo, com a atualização legislativa e a modernização de institutos como o do tombamento, busca-se o melhor método para a proteção do patrimônio cultural. Procura-se, igualmente, a 
forma menos penosa ao proprietário do bem e mais eficiente à Administração Pública, para a satisfação concomitante dos direitos culturais e do direito de propriedade.

\section{CONCLUSÃo}

O estudo foi dividido em duas partes, tratando a primeira da evolução histórica do tombamento e da temática de preservação do patrimônio histórico e cultural brasileiro. A segunda parte do trabalho de ateve à responder à problemática apresentada: o tombamento é, de fato, meio efetivo de preservação de bens histórica e culturalmente relevantes? Para tanto, utilizaram-se exemplos, notadamente os casos do edifício Wilton Paes de Almeida, em São Paulo, e do prédio Eunice Andrew, no Rio Grande do Sul. Analisou-se também a possibilidade de modernização da legislação atinente à proteção do referido patrimônio.

A matéria referente à preservação do patrimônio cultural teve relevância no país a partir dos anos 1930, uma vez que ganhou status constitucional com a Carta Magna de 1934. O tombamento, por sua vez, foi expresso no Decreto-Lei no 25/1937, sendo o método mais recorrente desde então para se alcançar o preceito constitucional. Recepcionada pela Constituição Federal de 1988, a Lei do Tombamento aumentou sua abrangência, aderindo ao conceito amplo de patrimônio cultural previsto no artigo 216 da Carta Cidadã.

Denota-se, todavia, que o instituto do tombamento não vem cumprindo sua missão constitucional. Exemplos como o Wilton Paes de Almeida, edifício abandonado em São Paulo e que desabou em virtude de um incêndio, e o Eunice Andrew, prédio demolido em Santa Maria após uma prolongada batalha judicial, evidenciam que o tombamento, por si só, não protege os bens culturais.

A condição de tombamento, na verdade, afasta a sociedade do propósito de proteção ao patrimônio histórico. Bens tombados, sobretudo os privados, são abandonados pelos proprietários pois eles não veem uma utilidade ou rentabilidade no imóvel, que se encontra estagnado no tempo em virtude de sua imodificabilidade. Os incentivos fiscais concedidos não compensam e a obrigação de eventualmente reparar o bem é irracional, de modo que o abandono e a deterioração são quase sempre o destino desses bens.

Outrossim, o processo de tombamento perante a Administração Pública se mostra moroso, ficando à mercê da burocracia e de decisões conflitantes, resultando muitas vezes no cancelamento do tombamento provisório, em virtude de clara ilegalidade e violação ao direito de propriedade.

O tombamento se mostra inefetivo tanto pela ação da sociedade, que demonstra de forma relapsa o cuidado com o patrimônio histórico e cultural do país, quanto por parte do Estado, que é ausente na fiscalização dos bens culturais e que dificulta, por meio de processos administrativos lentos, a efetivação do direito difuso à proteção desse patrimônio.

Nessa linha, considerando a insuficiência do tombamento para suprir o ideal constitucional de preservação do patrimônio histórico, bem como tendo vista o estado caótico da legislação 
atual, investigou-se também a necessidade de modernização das leis, mormente do Decreto-Lei $n^{\circ} 25 / 1937$.

Destacou-se, dentre o apresentado, a legislação portuguesa, que comporta todo um programa de promoção de ações de proteção não só ao patrimônio histórico português, mas à cultura lusitana. Considerando a influência da cultura portuguesa no Brasil, evidenciou-se a possibilidade de atualização da legislação cultural brasileira, tal qual a lei de Portugal.

Por fim, tem-se que o presente estudo foi de relevante importância, uma vez que refletiu a deficiência do instituto do tombamento, incapaz de cumprir o mandamento constitucional através do primitivo Decreto-Lei ${ }^{\circ}$ 25/1937. Ademais, a conclusão obtida com a pesquisa foi significativa, haja vista a necessidade de se propor meios mais eficientes e otimizados, com o fim de garantir o direito à proteção do patrimônio histórico e cultural.

\section{REFERÊNCIAS}

AGÊNCIA ESTADO. Dados indicam 40\% de imóveis tombados de SP destruídos. Estadão. São Paulo, 04 jan. 2009. Disponível em: https://bit.ly/2YDsDJu. Acesso em: 26 maio 2019.

BANDEIRA DE MELLO, Celso A. Curso de Direito Administrativo. 32.ed. São Paulo: Malheiros, 2015.

BARROSO, Luís Roberto. Curso de Direito Constitucional Contemporâneo: os conceitos fundamentais e a construção do novo modelo. 7.ed. São Paulo: Saraiva Educação, 2018.

BRASIL. Constituição da República Federativa do Brasil de 1988. Disponível em: https://bit.ly/ 3df4MUc. Acesso em: 10 abr. 2019.

BRASIL. Constituição da República dos Estados Unidos do Brasil de 1934. Disponível em: https://bit.ly/3dgXdwv. Acesso em: 10 abr. 2019.

BRASIL. Constituição dos Estados Unidos do Brasil de 1937. Disponível em: https://bit.ly/ 2WxoUds. Acesso em: 10 abr. 2019.

BRASIL. Decreto-Lei n. 25, de 30 de Novembro de 1937. Organiza a proteção do patrimônio histórico e artístico nacional. Disponível em: https://bit.ly/2Ws5JBW. Acesso em: 10 abr. 2019. 
BRASIL. Decreto no 3.551, de 04 de agosto de 2000. Institui o Registo de Bens Culturais de Natureza Imaterial que constituem patrimônio cultural brasileiro, cria o Programa Nacional do Patrimônio Imaterial e dá outras providências. Disponível em: http:/www.planalto.gov.br/ccivil_03/decreto/ d3551.htm. Acesso em: 26 abr. 2019.

BRASIL. Lei $\mathbf{n}^{\mathbf{0}} \mathbf{7 . 3 4 7}$, de 24 de julho de 1985. Disciplina a ação civil pública de responsabilidade por danos causados ao meio-ambiente, ao consumidor, a bens e direitos de valor artístico, estético, histórico, turístico e paisagístico (VETADO) e dá outras providências. Disponível em: https://bit. ly/2Wwe1Zr. Acesso em: 14 maio 2019.

BRASIL. Lei $\mathbf{n}^{\mathbf{0}}$ 9.605, de 12 de fevereiro de 1998. Dispõe sobre as sanções penais e administrativas derivadas de condutas e atividades lesivas ao meio ambiente, e dá outras providências. Disponível em: https://bit.ly/2WqzAe2. Acesso em: 25 abr. 2019.

BRASIL. Tribunal de Justiça do Estado de São Paulo. Apelação Cível nº 0034889-54.2011.8.26.0564. Décima Oitava Câmara de Direito Público. Relator: Roberto Martins de Souza. DJ: 08/05/2014. JusBrasil, 2014. Disponível em: https://bit.ly/35zRaAp. Acesso em: 27 maio 2019.

BRASIL. Tribunal de Justiça do Estado do Rio Grande do Sul. Apelação Cível no 70080937352. Segunda Câmara Cível. Relator: Lúcia de Fátima Cerveira. DJ: 24/04/2019. Porto Alegre, 2019. Disponível em: https://bit.ly/3cca3Mk. Acesso em: 28 maio 2019.

CARVALHO FILHO, José dos S. Manual de Direito Administrativo. 29.ed. São Paulo: Atlas, 2015.

CORDIDO, Ruth Maria Barros Reicao. O tombamento federal do patrimônio Cultural imobiliário. Revista Digital de Direito Administrativo, São Paulo, v. 2, n. 1, p. 293-310, 2015. Disponível em: https://bit.ly/2SFthSJ. Acesso em: 28 maio 2019.

COSTA, Rodrigo Vieira. A Dimensão Constitucional do Patrimônio Cultural: o tombamento e o registro sob a ótica dos direitos culturais. Rio de Janeiro: Lumen Juris, 2011.

DI PIETRO, Maria.S. Z. Direito Administrativo. 27.ed. São Paulo: Atlas, 2014.

EXAME. Profissionais criticam modelo de preservação de bens tombados no país. Disponível em: https://bit.ly/2xBu6Vm. Acesso em: 27 maio 2019. 
G1. Mais da metade dos bens tombados precisam de restauros em Campinas. Disponível em: https://glo.bo/2WxG7n5. Acesso em: 27 maio 2019.

II CONGRESSO INTERNACIONAL DE ARQUITETOS E TÉCNICOS DOS MONUMENTOS HISTÓRICOS - ICOMOS. Conselho Internacional de Monumentos e Sítios Escritório. Carta de Veneza de maio de 1964. Disponível em: https://bit.ly/2YC51Vy. Acesso: 12 abr. 2019.

INSTITUTO DO PATRIMÔNIO HISTÓRICO E ARTÍSTICO NACIONAL, IPHAN. Patrimônio Imaterial. Disponível em: https://bit.ly/2W69NZL. Acesso em: 26 abr. 2019.

JORNAL USP. Desabamento de prédio em São Paulo traz à tona a crise habitacional. Disponível em: https://bit.ly/2W5ilj1. Acesso em: 08 nov. 2018.

MAGALHÃES, José Geraldo. Reconstrução do Instituto Centenário. Disponível em: https://bit.ly/ 3b7P6k8. Acesso em: 29 maio 2019.

MATGE, Pâmela R. Colégio Centenário e prefeitura divergem sobre demolição de ruínas. Disponível em: https://bit.ly/2WxpMyK. Acesso em 09 nov. 2018.

MEIRELLES, Hely Lopes. Direito Administrativo Brasileiro. 41.ed. atualizado por Délcio Balestero Aleixo; José Emmanuel Burle Filho. São Paulo: Malheiros, 2015.

MESQUITA, Lígia; SOUZA, Felipe; BARIFOUSE, Rafael. De luxo modernista a ocupação precária: a história de mais de meio século do prédio que desabou em São Paulo. Disponível em: https:// bbc.in/3fgFaZ0. Acesso em: 28 maio 2019.

MURARO, Cauê. Edifício Wilton Paes de Almeida: prédio que desabou em SP foi projetado na década de 1960 e era patrimônio histórico. Disponível em: https://glo.bo/2ymjQ3V. Acesso em: 08 nov. 2018.

NASCIMENTO, Thatiany. Bens tombados provisoriamente aguardam há mais de 10 anos proteção definitiva em Fortaleza. Disponível em: https:/glo.bo/3fnZQyp. Acesso em: 27 maio 2019.

PIRES, Maria Coeli Simões. Da Proteção ao Patrimônio Cultural: o tombamento como principal instituto. Belo Horizonte: Del Rey, 1994. 
PORTUGAL. Lei $\mathbf{n}^{\mathbf{0}}$ 107, de 8 de setembro de 2001. Estabelece as bases da política e do regime de protecção e valorização do património cultural. Disponível em: https://bit.ly/3fpxlQM. Acesso em: 29 maio 2019.

RABELLO, Sonia. O Estado na preservação dos bens culturais: o tombamento. Rio de Janeiro: IPHAN, 2009.

REIS, Émilien V. B.; FONSECA, Renato P. A Inefetividade do Tombamento na Proteção do Patrimônio Cultural Arquitetônico no Município de São Paulo. Disponível em: https://bit.ly/2SBJGYA. Acesso em: 04 out. 2018.

RIO GRANDE DO SUL. Lei $\mathbf{n}^{\mathbf{0}}$ 7.231, de 18 de dezembro de 1978. Dispõe sobre o patrimônio cultural do Estado. Porto Alegre: Assembleia Legislativa do Estado do Rio Grande do Sul, 1978. Disponível em: https://bit.ly/2Ws6OK0. Acesso em: 21 maio 2019.

SANTA MARIA. Lei Orgânica do Município, de 03 de abril de 1990. Santa Maria: Câmara Municipal de Vereadores, 1990. Disponível em: https://bit.ly/2L5rbHz. Acesso em: 21 maio 2019.

SANTA MARIA. Lei no 3.999, de 24 de setembro de 1996. Dispõe sobre a proteção do patrimônio histórico e cultural do Município de Santa Maria, e dá outras providências. Santa Maria: Câmara Municipal de Vereadores, 1996. Disponível em: https://bit.ly/2YBPghh. Acesso em: 21 maio 2019.

SCAFF, Fernando F. Prédio que desabou em SP foi destinado a Faculdade de Direito da Unifesp. Disponível em: https://bit.ly/3c9oQHs. Acesso em: 28 maio 2019.

SILVA Silvana \& MATGE, Pâmela R. VÍDEO: ruínas do Colégio Centenário começam a ser demolidas 11 anos após incêndio. Disponível em: https://bit.ly/2YJiQBk. Acesso em 09 nov. 2018.

TOMASEVICIUS FILHO, Eduardo. O tombamento no direito administrativo e internacional. Disponível em: https://bit.ly/2WnXSVS. Acesso em: 11 abr. 2019. 
